Proc. Estonian Acad. Sci. Geol., 2002, 51, 1, 33-46

\title{
Porosity structure of Icelandic basalt
}

\author{
Omar Sigurdsson and Valgardur Stefansson \\ Orkustofnun, Grensasvegur 9, IS-108 Reykjavik, Iceland; omar@os.is, vs@os.is \\ Received 7 February 2001, in revised form 12 June 2001
}

\begin{abstract}
Systematic sampling of igneous rocks from extinct geothermal systems in the Icelandic crust has resulted in a database covering most types of geothermal reservoir rocks presently under exploitation in Iceland. At present, the database includes more than 500 samples spanning the basaltic to rhyolitic composition and hydrothermal alteration from literally fresh rocks to greenschist facies rocks. The database is used to study the relationship between different reservoir parameters, such as thermal conductivity and porosity, alteration, and permeability. The present paper describes the relationship between porosity and permeability and the information that can be derived from this data set. It is found that the average difference between effective and total porosities is about $2 \%$ and that this difference is independent of porosity over the range $0-50 \%$. This demonstrates that the whole pore volume in these igneous rocks is effective for fluid flow through them. The permeability measured with liquid brine is systematically lower than that obtained by measurements using air or gas. Brine permeability is on average three times lower than gas permeability measured on the same sample. We explain this discrepancy as a result of the formation of a connate liquid film that adheres to the rock in combination with capillary forces that reduce and block portions of the flow paths for the liquid flow. Reasonable conversion of gas permeability to brine permeability can be obtained by taking into account the effect of immobilization of part of the brine. This supports the view that a film of connate brine causes the difference in the observed permeability values. The bundle capillary tube model seems to be the best model describing the porosity structure of the Icelandic rocks, whereas the Kozeny-Carman model shows very weak correlation to the data. The calculated tube diameters of the bundle capillary tube model are in the range $0.03-80 \mu \mathrm{m}$, while laboratory measurements on only a few samples gave values in the range $0.05-100 \mu \mathrm{m}$. The calculated diameters of the majority of the samples are less than $0.7 \mu \mathrm{m}$, or smaller than the wavelength of visible light.
\end{abstract}

Key words: igneous rock, porosity structure, permeability, basalt, capillary tube model, rock database, geothermal systems.

\section{INTRODUCTION}

Rock samples of igneous origin have been collected in Iceland to study their reservoir physical properties. At present, the collection contains more than 500 samples spanning the basaltic to rhyolitic composition including lavas, hyaloclastites, 
intrusions, and a few sedimentary rocks of volcanic origin. The hydrothermal alteration of the samples varies from literally fresh rocks to true greenschist facies rocks. The samples cover most rock types and alteration found in active low and high enthalpy geothermal systems in Iceland. Iceland is located in the spreading zone of the Mid-Atlantic ridge of intense volcanic activity, and consequently the majority of the samples are of basaltic composition (Table 1). Petrological and mineralogical studies as well as chemical analysis have been conducted on more than half of the samples. Most of the samples have been measured with respect to gas permeability, porosity, and grain density (Table 2). Part of the samples has undergone more specialized measurements of acoustic velocity, thermal conductivity, resistivity, and mercury injection.

Results from measurements and studies of these rock samples form a database on the petrophysical properties of the host rocks of Icelandic geothermal systems. The objective is to compare the laboratory measurements with the results obtained from geophysical logs and the best fit parameters acquired from mathematical modelling of geothermal systems. In that way the petrophysical results are expected to be transferable onto presently active geothermal systems. The contribution focuses on the petrophysical results obtained from porosity and permeability measurements and discusses the relationships between those parameters.

\section{SAMPLING AND MEASUREMENTS}

Iceland lies on the Mid-Atlantic ridge, characterized by intense volcanic activity. The volcanic and tectonic activity is mostly confined to the neovolcanic zone that crosses the island from southwest to northeast and is the continuation of the ridge on land (Saemundsson 1979). Due to the spreading of the ridge, active high enthalpy systems drift out from the volcanic zone, cool down, and eventually die out. The geological formations are relatively young ( $<17$ million years) and mostly of basaltic type.

The most realistic way to obtain samples of geothermal reservoir rocks is to take core samples during drilling a well. This is, however, a rather expensive sampling method, and few cores are currently available from Icelandic geothermal wells. In order to obtain a statistically representative number of samples at a reasonable cost, it was decided to make surface sampling of rocks compatible to the rocks found in active geothermal systems. One way of meeting this objective was to carry out systematic sampling from eroded sections of the Icelandic upper crust. In this geological environment, the rocks from fossil low and high enthalpy geothermal systems can be sampled easily and systematically. It is assumed that the petrophysical characteristics of the rocks have not changed significantly from the time when the geothermal systems were active to their present fossil state at the surface. Figure 1 shows the main sampling sites and Table 1 summarizes the distribution of the samples into rock types and alteration state. Of the 509 samples collected, only about 40 were taken during drilling operations. 


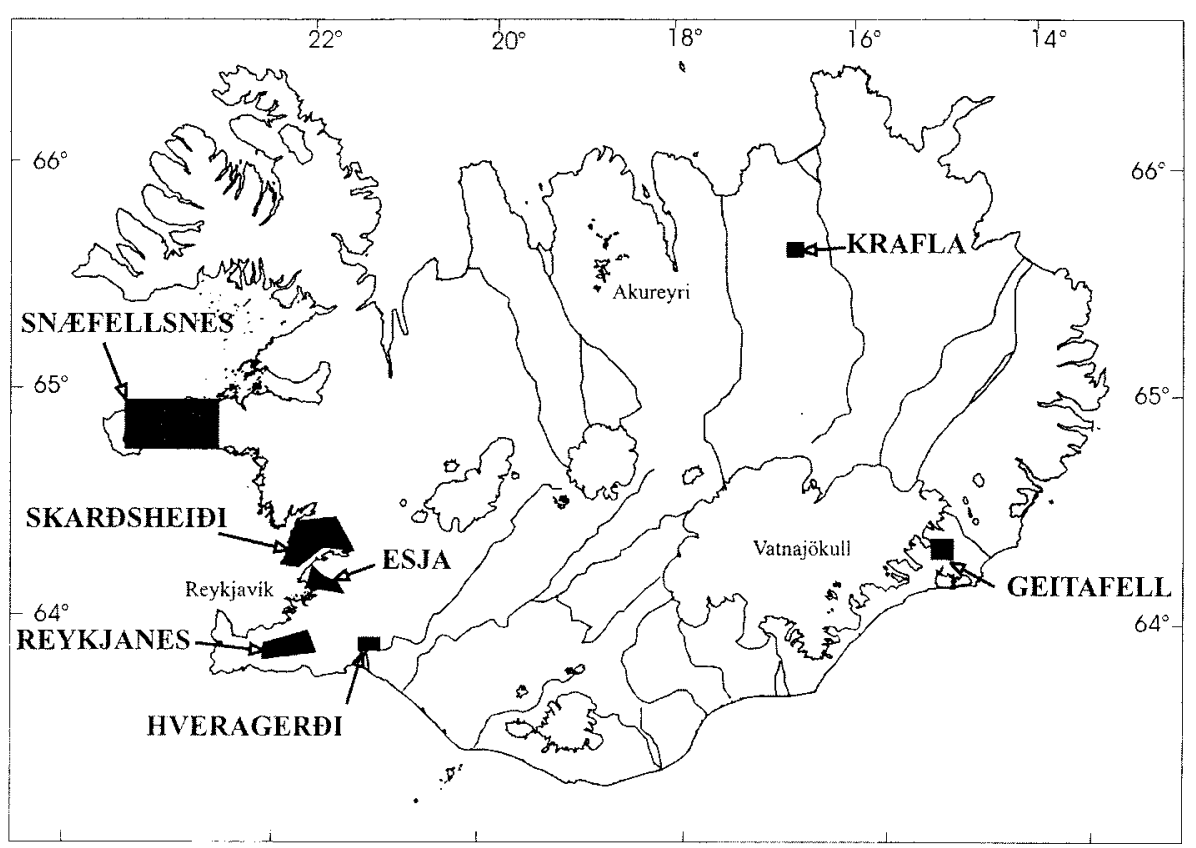

Fig. 1. Location of sampling sites in Iceland.

Table 1. Classification of samples with respect to rock types and alteration stage

\begin{tabular}{|c|c|c|c|c|c|c|c|}
\hline \multirow[t]{2}{*}{ Rock type } & \multicolumn{7}{|c|}{ Alteration stage } \\
\hline & Unaltered & $\begin{array}{c}\text { Smectite/ } \\
\text { zeolites }\end{array}$ & $\begin{array}{c}\text { Mixed } \\
\text { layer clay }\end{array}$ & Chlorite & $\begin{array}{c}\text { Chlorite/ } \\
\text { epidote }\end{array}$ & $\begin{array}{c}\text { Epidote/ } \\
\text { amphibole }\end{array}$ & Total \\
\hline \multicolumn{8}{|l|}{ Basaltic } \\
\hline Lavas & 122 & 44 & 22 & 2 & 42 & 36 & 268 \\
\hline Hyaloclastites & 30 & 21 & 8 & 3 & 6 & 1 & 69 \\
\hline Intrusions & & 24 & 12 & 6 & 30 & 36 & 108 \\
\hline Andesites & & 5 & & & 2 & 2 & 9 \\
\hline Acid rocks & & 25 & & & 11 & 12 & 48 \\
\hline Sediments & 2 & 3 & & & 1 & 1 & 7 \\
\hline Total & 154 & 122 & 42 & 11 & 92 & 88 & 509 \\
\hline
\end{tabular}

Thin sections were made for all samples, and the rock type and degree of hydrothermal alteration were determined petrographically with greater accuracy than was possible in the field. Point counting of thin sections was used to determine the degree of alteration of the original rock and volume of secondary minerals. The thin section study distinguishes between gas vesicles and intercrystalline pores, 
primary and secondary minerals, and reprecipitation of minerals in pores or fractures. This petrological and mineralogical study is supported by chemical analysis of about half the samples. Its objective is to quantify the effect of chemical transport and hydrothermal alteration on other physical parameters such as porosity and permeability.

The majority of the samples have gone through basic poreperm measurements to determine gas permeability, effective porosity, and effective grain density. Part of the samples has undergone more specialized measurements of acoustic velocity, thermal conductivity, and resistivity. Table 2 summarizes the measurements available for the collected samples, but the objective is to establish predictive relationships between the core measurements and easily obtainable geophysical logs in boreholes.

Table 2. Available measurements for the rock samples

\begin{tabular}{l|c|c|r}
\hline \multicolumn{1}{c}{ Measurement } & Saturated & Dry & Total \\
\hline Air or gas permeability & & 411 & 411 \\
Water permeability & 85 & & 85 \\
Effective porosity & & 483 & 483 \\
Total porosity & & & 216 \\
Effective grain density & & 483 & 483 \\
Total grain density & 50 & & 216 \\
Resistivity & 2 & 57 & 50 \\
Thermal conductivity & 10 & 98 & 59 \\
Acoustic velocity $V_{\mathrm{p}}$ & 10 & 21 & 108 \\
Acoustic velocity $V_{\mathrm{s}}$ & & & 31
\end{tabular}

\section{POROSITY}

Effective porosity has been measured by He-gas expansion and total porosity by volumetric difference from immersion into $\mathrm{Hg}$-fluid, first in the bulk and later in the crushed sample. The porosity distribution is relatively even. The porosity in the igneous samples has been found to be as high as $49 \%$, but in most of the samples it falls below 20\%. Noticeable is the absolute difference between effective and total porosities (Sigurdsson \& Stefansson 1994). In the Icelandic rocks it is generally only $1-2 \%$ (Fig. 2) and appears to be independent of the porosity (Stefansson et al. 1997). Despite vesicular pores in fresh basaltic lavas this appears to apply to all the rock types in the sample selection. Since the effective porosity represents the volume in the rock which is open to flow, it can be concluded for Icelandic reservoir rocks that nearly all pores are connected.

The porosity determined from thin section point counting is generally about $5 \%$ lower than that measured by the He-gas expansion. This difference can become much higher in young and unaltered formations (Franzson et al. 1997), but 


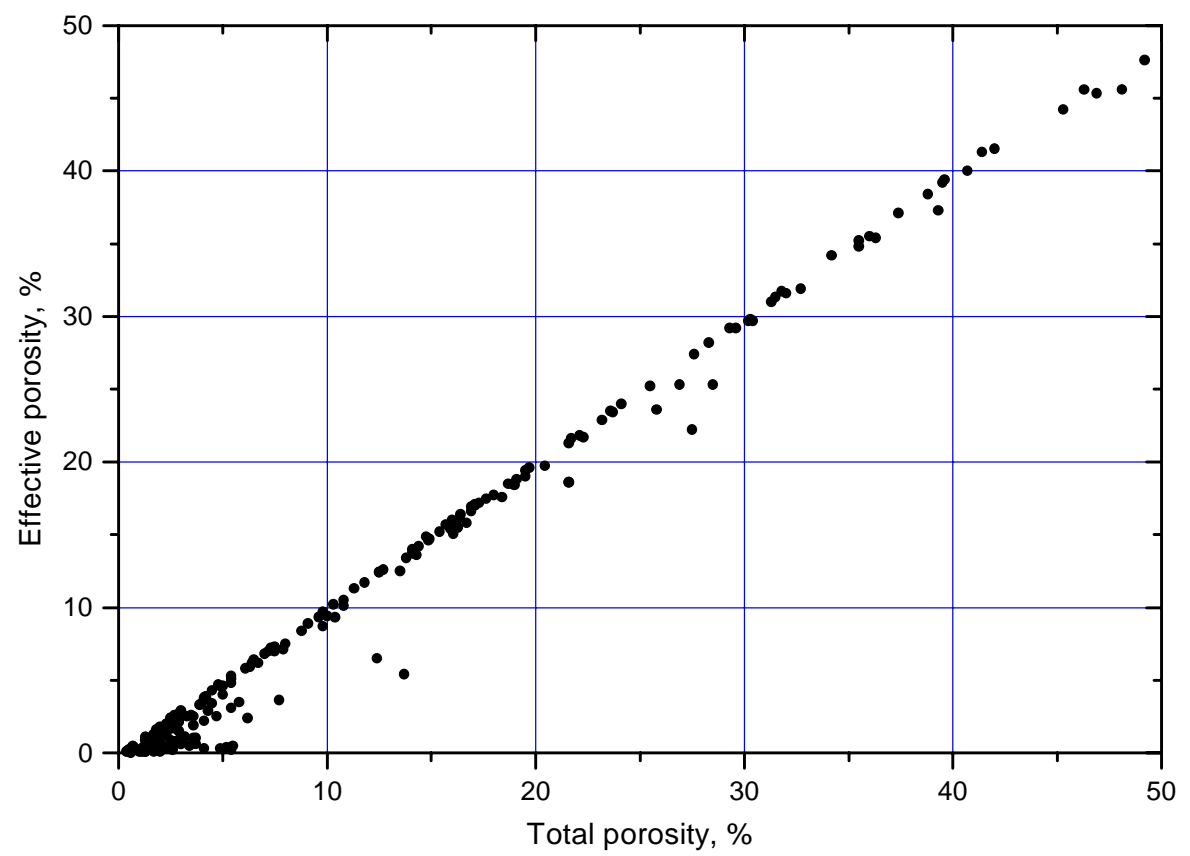

Fig. 2. The correlation between effective and total porosities.

generally it increases slightly by a higher alteration state and becomes more pronounced at a higher alteration stage than $85 \%$. The explanation for the large difference in the unaltered rock samples could be that most of those samples are olivine-tholeiite basalt, where microporosity or intercrystalline porosity are more common than in more evolved rock types. It is also implied that micropores may increase in number with increasing alteration, especially in highly altered samples. Normal thickness of a thin section is about $30 \mu \mathrm{m}$ and therefore it is difficult to detect a pore space smaller than that.

\section{PERMEABILITY}

Permeability is generally considered to be a physical property of the rock (Amyx et al. 1960). By that definition, the use of different fluids to measure permeability should yield results within the error limits of the method applied. In theory this is the case, but in practice the outcome of the measurements can turn out to be quite different depending on the fluid used. There are many possible reasons for this, and the one commonly mentioned states that brine may react with the minerals in the samples thereby reducing, clogging, or narrowing the flow paths through the rock samples. On the other hand, the driving force of the 
gas can cause alteration in the flow path through the rock sample and thereby affect the results. This phenomenon is not widely discussed in the literature, although it is likely to be quite common.

Permeability has been measured with $(\mathrm{He}, \mathrm{N})$ gas for the majority of the igneous Icelandic samples and with brine for nearly $20 \%$ of them (Table 2). The results show that the liquid permeability is consistently lower than the gas permeability (Fig. 3). On average, the measured liquid permeability is about three times lower than the corresponding gas permeability. The observed difference in flow resistance between the two fluids is here considered to be controlled by other factors than mentioned earlier. It is thought that the difference is partly related to the measurement technique. The gas measurement is carried out on dry samples, while the brine measurement is performed on saturated samples. While the sample is dry, all pores and flow paths are open for flow. When saturated, a connate liquid film adheres to the rock and in combination with capillary forces reduces and blocks portions of the flow paths for liquid flow. Similar differences in permeability measurements using gas and brine have been observed for sedimentary rocks from the North Sea (Juhasz 1986). Furthermore, it appears that an empirical relationship developed to convert gas permeability values to brine permeability values for sedimentary rocks also applies to the Icelandic igneous rock samples (Sigurdsson 1998a).

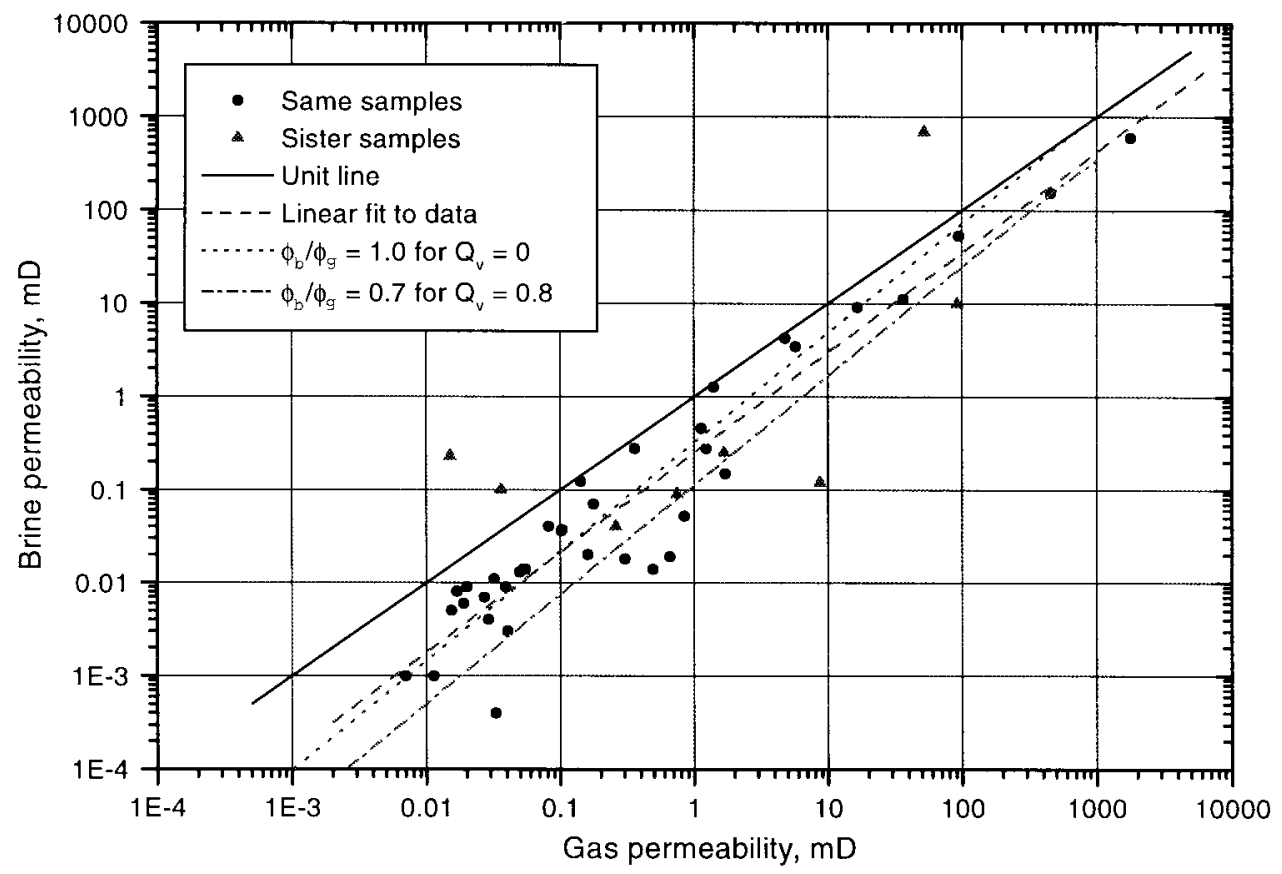

Fig. 3. Relationships between gas and brine permeabilities. 
A relationship to convert gas permeability values to brine permeability values was introduced by Swanson (1981). It is based on correlations between permeabilities and mercury capillary pressure measurements on samples from carbonates and sandstone formations. Equating the correlations through the common correlating parameter (ratio of mercury saturation to capillary pressure) and applying a clay-bound water correction, Juhasz (1986) arrived at an improved conversion formula. The effect of immobilization of a part of the brine is inherent in the correlation, but it has the following form:

$$
k_{\mathrm{b}}=A k_{\mathrm{g}}^{B}\left(\phi_{\mathrm{b}} / \phi_{\mathrm{g}}\right)^{C},
$$

where $k_{\mathrm{b}}$ and $k_{\mathrm{g}}$ are the brine and gas permeabilities, the parameters $A, B$, and $C$ are dependent on effective stress, $\phi_{\mathrm{g}}$ is the porosity open for gas flow, which should be the same as the effective porosity, and $\phi_{\mathrm{b}}$ is the porosity open for brine flow. Included in the ratio $\phi_{\mathrm{b}} / \phi_{\mathrm{g}}$ are effects of salinity and shaliness. This relationship appears to be just as applicable to the igneous rock samples as to the sedimentary rock samples. Figure 3 shows two correlation lines for that relationship. One line shows the case where the available pore space for brine flow is equal to the effective pore space of the sample. The other line represents the case where the available pore space for brine flow is less than the effective porosity of the sample. To improve on the correlation, the $\phi_{\mathrm{b}} / \phi_{\mathrm{g}}$ ratio would be needed for each sample, but that requires determination of the shaliness indicator $\left(Q_{v}\right)$ which is a measure of exchangeable cations in the sample.

The relationship between porosity and permeability is being studied in a search for a predictive model for permeability in Icelandic igneous rocks. Most models available in the literature, which connect permeability to other rock parameters characterizing the pore structure, are based on simple geometries (Hearst \& Nelson 1985). Commonly, the models are derived by combining Poiseuille's law, which gives the average flow in a cylindrical tube, with Darcy's law for flow in porous media. The resulting relationship has been written in many different ways, depending on the material being studied. Two forms of the relationship are written as

$$
k=\frac{D^{2}}{32\left(L_{\mathrm{e}} / L\right)^{2}} \times \phi
$$

for the bundle capillary tube model and as

$$
k=\frac{1}{k_{0}\left(L_{\mathrm{e}} / L\right)^{2} S_{0}^{2}} \times \frac{\phi^{3}}{(1-\phi)^{2}}
$$

for the Kozeny-Carman model. The parameters in the above equations are the tube diameter $(D)$, permeability $(k)$, porosity $(\phi)$, effective length of flow path $\left(L_{\mathrm{e}}\right)$, length of sample $(L)$, shape factor $\left(k_{0}\right)$, and ratio of pore surface to grain volume $\left(S_{0}\right)$. The tube diameter corresponds to the pore throat diameter, and the length ratio $\left(L_{\mathrm{e}} / L\right)$ describes the tortuosity. Rearranging the above equations 
by grouping the unknown parameters on one side and the known parameters on the other, the plots in Figs. 4 and 5 are obtained. Figure 4 indicates none or at most weak relation with the Kozeny-Carman model, while Fig. 5 shows a strong relation to the capillary tube model. Further work attempting to relate measured parameters to permeability has revealed that dependence on porosity appears to be weak for samples with porosities less than 18-20\% (Sigurdsson 1998b). This is demonstrated in Fig. 6 showing an optimal transform of the porosity data, which can be used in a nonparametric regression algorithm (Xue et al. 1997). It means that the pore throats or the flow paths connecting pores control the flow of fluids through the rocks, but not the bulk volume of the pores. A thin-section study on a relatively fresh olivine-tholeiite basalt from a batch of the samples revealed that the larger gas vesicles were often nearly blocked or isolated by glass at the vesicle rims while smaller intercrystalline pores were open (Fridleifsson \& Vilmundardottir 1998). Results of measurements made on a few samples under varying confining pressure further support the capillary tube flow model behaviour as the different parameters measured showed little dependence on confining pressure (Johnson \& Boitnott 1998).

Samples of basaltic hyaloclastites, andesites, acid rocks, and volcanic sediments (Table 1) all correlate to the capillary tube model, while some samples of basaltic lavas and basaltic intrusions deviate from that model. Looking closer at the rock

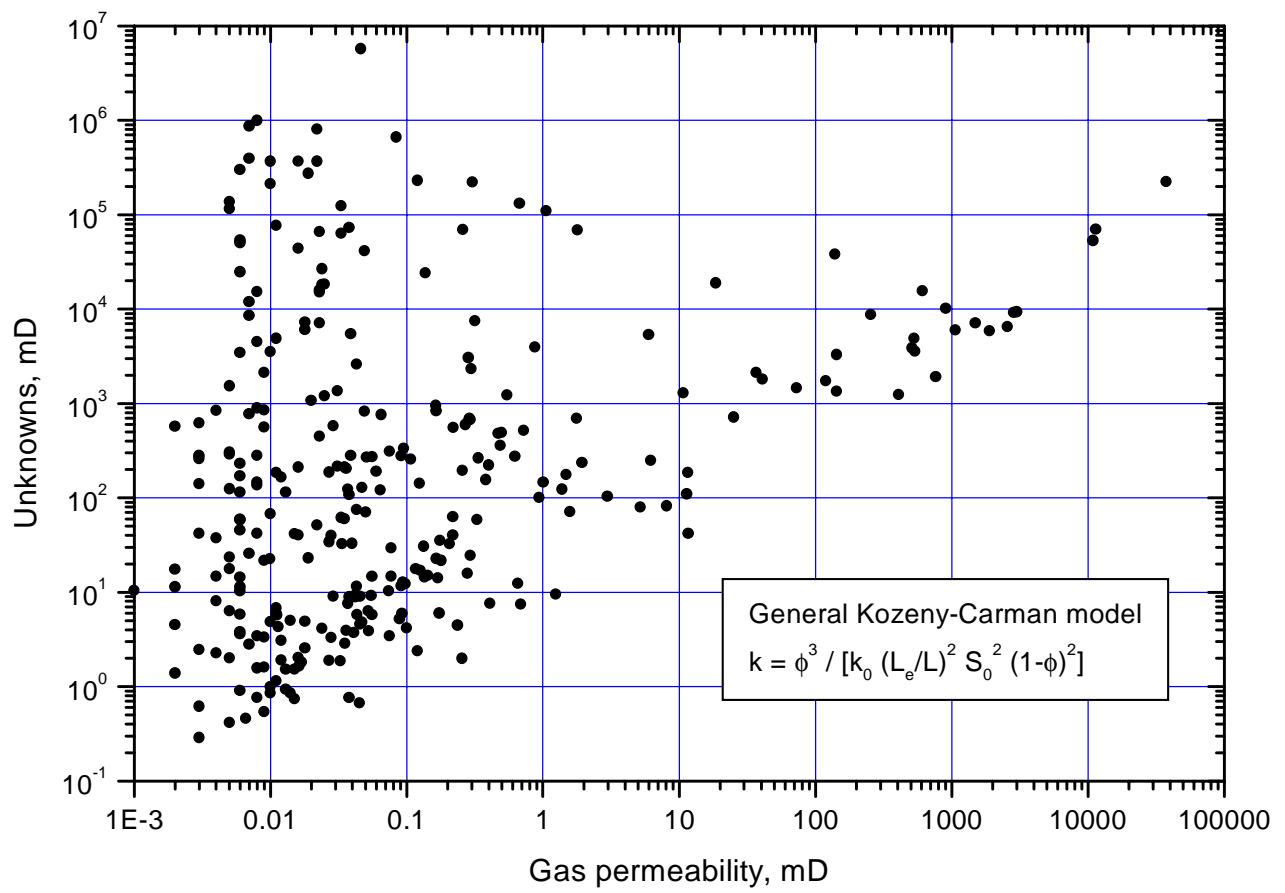

Fig. 4. Relation of unknowns in the Kozeny-Carman model to permeability indicating weak permeability-porosity relationship for that model. 


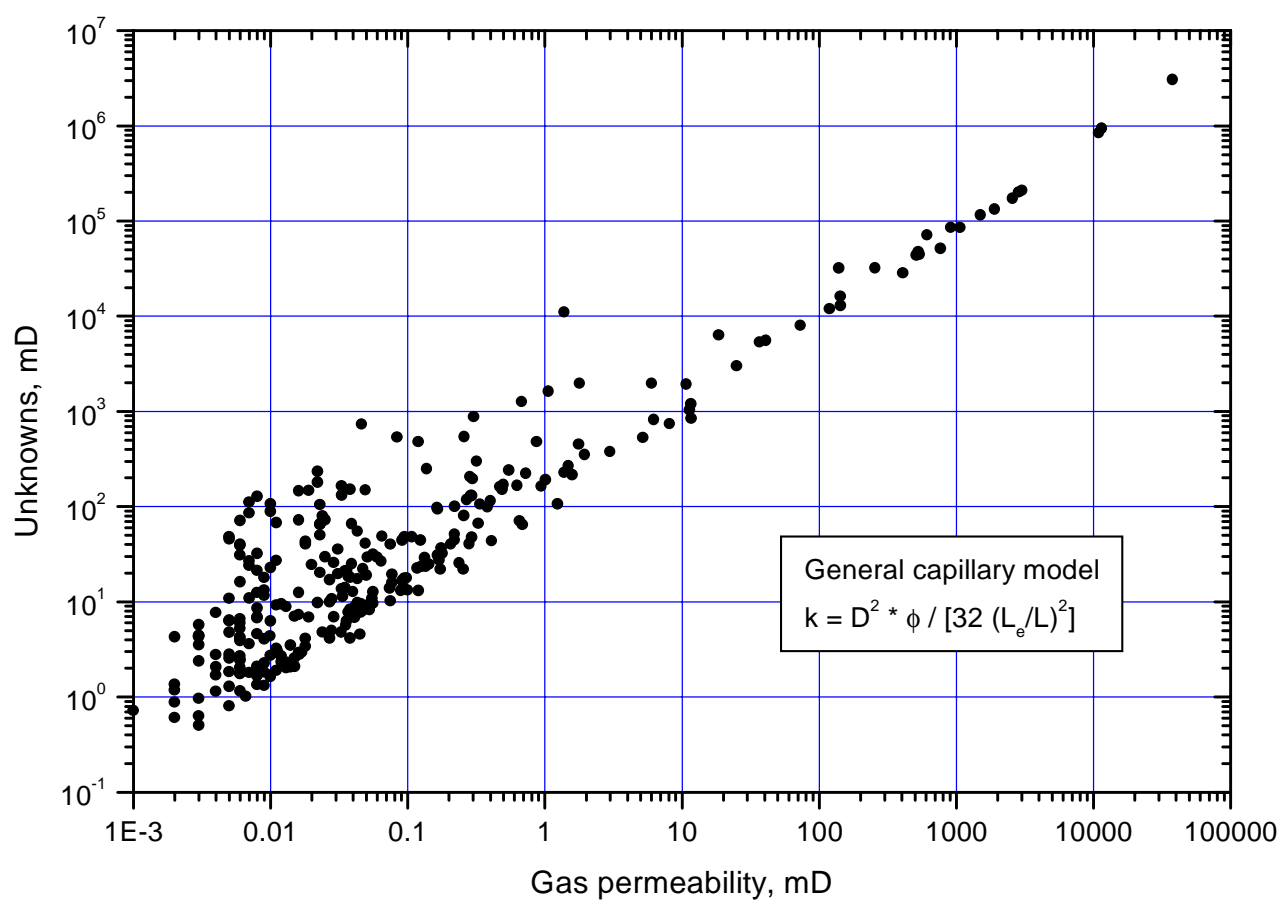

Fig. 5. Relation of unknowns in the capillary tube model to permeability indicating strong permeability-porosity relationship for that model.

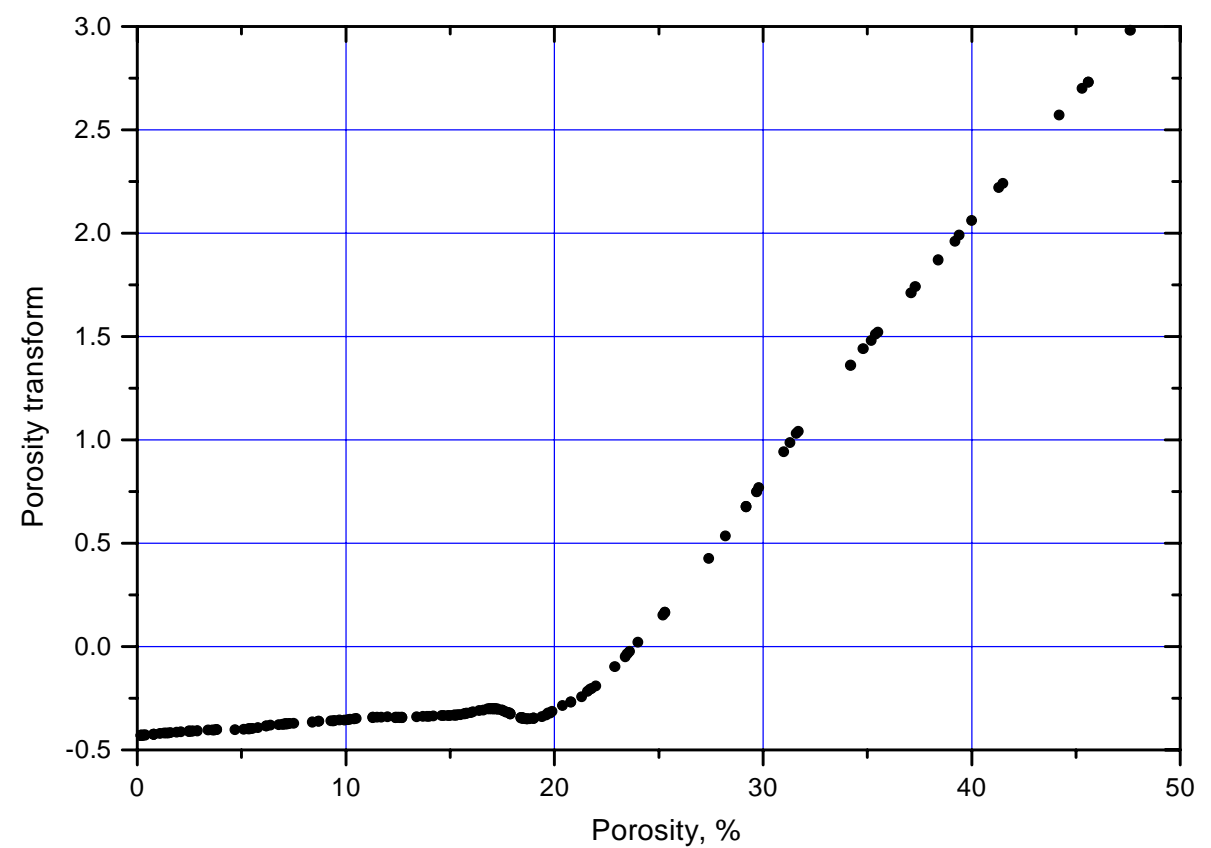

Fig. 6. Ordered optimal transform of the porosity data for the alternating conditional expectation algorithm (see Xue et al. 1997). 
types that deviated from the capillary tube model, it was found that the basalt lava samples represented the alteration stages smectite/zeolites and chlorite/epidote. As mentioned earlier, the results of the thin-section studies indicate a reduction in permeability for a low degree of alteration (smectite/zeolites), supposedly caused by clogging of pore throats. Therefore, the flow paths in these samples might be more dispersed, which means that their tortuosity factor could be higher than for the other samples. The intrusion samples came from the chlorite/epidote and epidote/amphibole alteration stages. Figure 7 shows the basaltic samples plotted for the capillary tube model with the implication that a higher tortuosity factor for the deviating samples would lessen the spread in the graph and strengthen the porosity-permeability relationship.

Based on a capillary tube model and assuming a fixed value of 1.73 for the tortuosity factor $\left(\tau=\left[L_{\mathrm{e}} / L\right]^{2}\right)$, a controlling tube diameter has been calculated, using the above equation, which is assumed to represent the pore throat diameter of the highest frequency in the sample. Results of measurements on a few samples indicate that the pore throat diameters are grouped on a narrow width band for a given sample. The calculated tube diameters are in the range $0.03-80 \mu \mathrm{m}$ (Fig. 8), while measurements on a few samples have given diameters in the range $0.05-100 \mu \mathrm{m}$. The majority of the calculated diameters for the samples is less than $0.7 \mu \mathrm{m}$, or shorter than the wavelength of visible light $(0.4-0.7 \mu \mathrm{m})$.

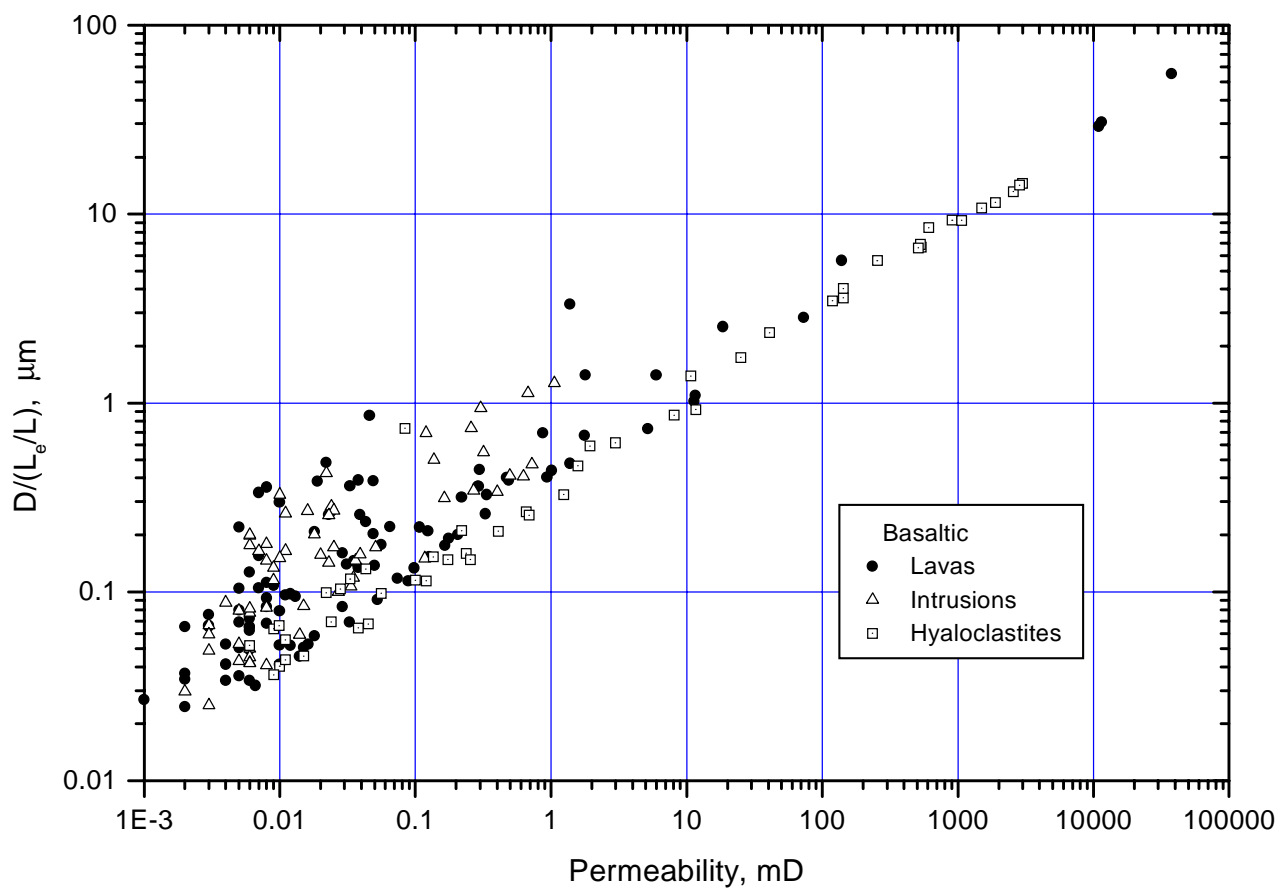

Fig. 7. Indication of the permeability-porosity relationship for the basaltic samples to the capillary tube model. 


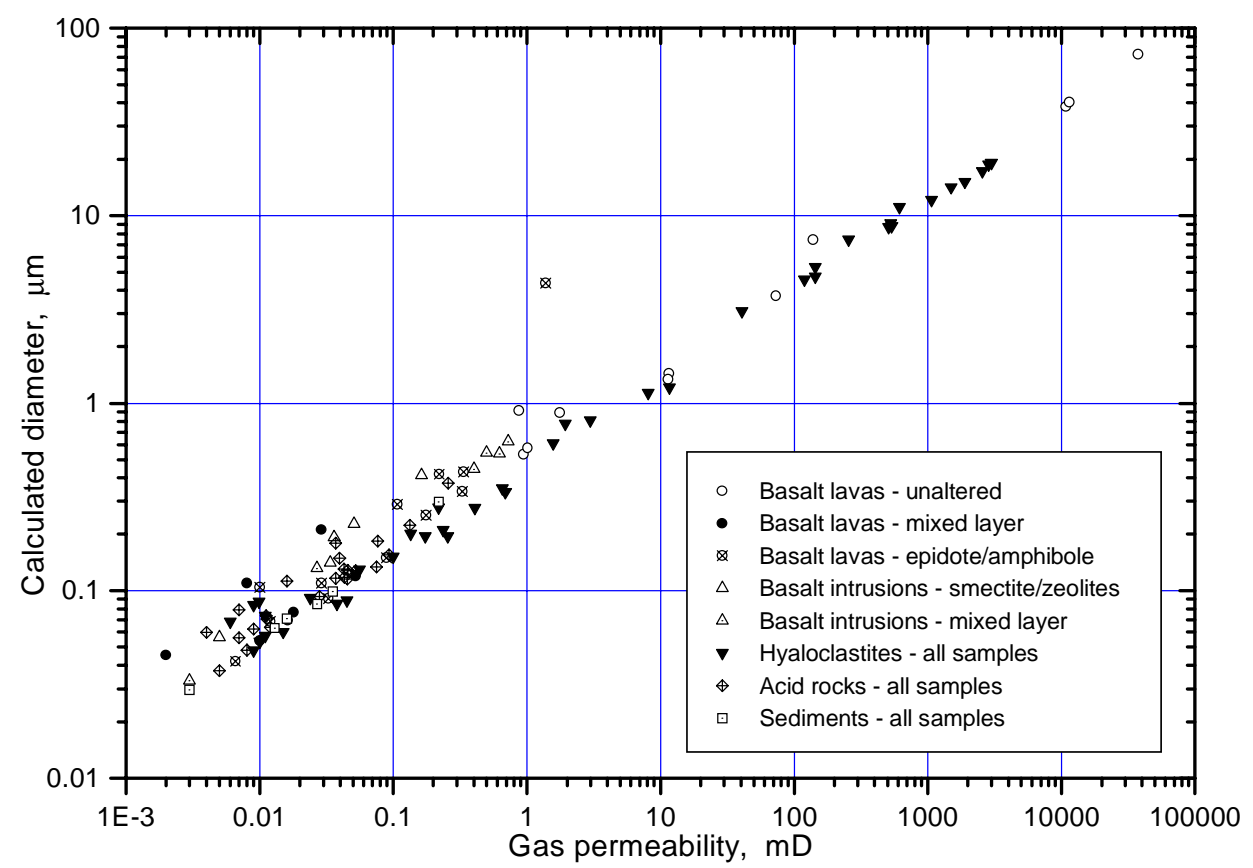

Fig. 8. Calculated pore throat diameters for all the samples that strongly relate to the capillary tube flow model.

\section{DISCUSSIONS AND CONCLUSIONS}

Transmissivity and hence the productivity of geothermal reservoirs is generally dominated by fractures. However, the bulk of their fluid storage is within the rock matrix, and the rock parameters, such as permeability and porosity, control the productivity decline and longevity of the reservoirs. It is therefore imperative to have a greater understanding of the physical properties of the matrix rocks that compose the geothermal systems.

The rock types in Icelandic geothermal systems are of igneous origin and mostly basaltic. Investigations into reservoir parameters of igneous rocks have not been as extensive as corresponding studies of sedimentary rocks that compose the oil and gas reservoirs. Our results show that similarities can be found between igneous and sedimentary rocks. The physical behaviour and response to a given agitation can be similar in both the igneous and sedimentary rocks. The results obtained and relationships developed may therefore have a broader application.

Firstly, the results for igneous rocks indicate that the hyaloclastites are the preferred reservoir matrix for the Icelandic geothermal systems. The hyaloclastites have generally higher porosities and permeabilities than the basaltic lavas and intrusions. 
A small difference of only $1-2 \%$ is observed between effective and total porosities for the majority of the rock samples.

The empirical relationship developed for sedimentary rocks can also be used to transfer the measured gas permeability for igneous rocks to equivalent liquid permeability.

Most of the samples collected match the capillary tube type of the predictive model for permeability. The results also show that the pore throats diameters for the majority of the samples are less than the wavelength of visible light $(0.4-0.7 \mu \mathrm{m})$.

\section{ACKNOWLEDGEMENTS}

The authors thank Orkuveita Reykjavíkur for its support to this project and Alla Shogenova and Steve Ogilvie for reviewing the manuscript.

\section{REFERENCES}

Amyx, J. W., Bass, D. M. Jr. \& Whiting, R. L. 1960. Petroleum Reservoir Engineering. Physical Properties. McGraw-Hill.

Franzson, H., Fridleifsson, G. O., Gudmundsson, A. \& Vilmundardottir, E. G. 1997. Forðafraððistuðlar. Staðabergfræeðirannsókna í lok 1997. [Reservoir parameters. Status of petrological studies by the end of 1997.] Report Orkustofnun OS-97077 (in Icelandic).

Fridleifsson, G. O. \& Vilmundardottir, E. G. 1998. Reservoir Parameters TCP-Project. A ThinSection Study of the Öskjuhlí Samples. Report Orkustofnun OS-98041.

Hearst, J. R. \& Nelson, P. H. 1985. Well Logging for Physical Properties. McGraw-Hill.

Johnson, J. \& Boitnott, G. N. 1998. Velocity, Permeability, Resistivity and Pore Structure Models of Selected Basalts from Iceland. New England Research, Vermont, U.S.A.

Juhasz, I. 1986. Conversion of routine air-permeability data into stressed brine-permeability data. In Transactions, Tenth European Formation Evaluation Symposium. Aberdeen, UK, paper Y.

Saemundsson, K. 1979. Outline of the geology of Iceland. In Geology of Iceland (Thorarinsson, S. \& Saemundsson, K., eds.). Jökull, 29, 7-28.

Sigurdsson, O. \& Stefansson, V. 1994. Forðafraðistuðlar. Maclingar á bergsýnum. [Reservoir parameters. Measurements on rock samples.] Report Orkustofnun OS-94049/JHD-28 B (in Icelandic).

Sigurdsson, O. 1998a. Forðafræðistuðlar. Reynslusamband til að breyta maldri gaslekt í vatnslekt. [Reservoir parameters. An empirical relationship to change measured gas permeability to water permeability.] Report Orkustofnun OS-98065 (in Icelandic).

Sigurdsson, O. 1998b. Forðafraððistuðlar. Lekt og hárpípulíkan. [Reservoir parameters. Permeability and capillary tube model.] Report Orkustofnun Omar-1998/01 (in Icelandic).

Stefansson, V., Sigurdsson, O., Gudmundsson, A., Franzson, H., Fridleifsson, G. O. \& Tulinius, H. 1997. Core measurements and geothermal modelling. In Second Nordic Symposium on Petrophysics, Fractured Reservoirs (Middleton, M. F., ed.). Nordic Petroleum Technology Series: One, 198-220.

Swanson, B. F. 1981. A simple correlation between permeabilities and mercury capillary pressure. J. Petrol. Technol., 33, 2498-2504.

Xue, G., Datta-Gupta, A., Valkó, P. \& Blasingame, T. 1997. Optimal transformations for multiple regression: application to permeability estimation from well logs. SPE Formation Evaluation, 12, 85-93. 


\title{
Islandi basaltide poorsus
}

\author{
Omar Sigurdsson ja Valgardur Stefansson
}

Islandi maakoore kustunud geotermiliste süsteemide tardkivimite proovide andmebaas haarab enamikku tänapäeval Islandil kasutatavate kollektorkivimite tuiüpidest. Andmebaasis on üle 500 proovi, mille koostis ulatub basaldist lipariidini ja hüdrotermilised muutused varieeruvad värskest kivimist rohekilda faatsieseni. Andmebaas on kollektorite parameetrite seoste uurimise aluseks.

Artiklis on kirjeldatud poorsuse ja veejuhtivuse suhet. Efektiivpoorsuse ja üldpoorsuse vahe on keskmiselt $2 \%$ ja see ei olene poorsuse väärtusest vahemikus 0-50\%. Seega on kogu pooride maht vedelike läbivoolul kivimitest efektiivne. Ühes ja samas proovis mõõdetud soolvee läbilaskvus on keskmiselt kolm korda väiksem kui gaasi läbilaskvus. Autorite arvates on lahknevus tingitud kivimile liibuvast vedelikukelmest, mis koos kapillaarjõududega blokeerib voolutee või vähendab seda. Kapillaartorude kimpmudel näib olevat parim mudel Islandi kivimite poorse tekstuuri kirjeldamiseks. Kozeny-Carmani mudeli puhul on korrelatsioon andmetega väga väike. Kapillaartorude kimpmudeli arvutuslikud torude läbimõõdud on piires $0,03-80 \mu \mathrm{m}$. Väga vähesed laboratoorsed mõõtmised annavad väärtusi vahemikus $0,05-100 \mu \mathrm{m}$. Enamasti on proovide puhul arvutatud läbimõõdud väiksemad kui $0,7 \mu \mathrm{m}$, seega väiksemad kui nähtava valguse lainepikkus.

\section{Структура пористости исландских базальтов}

\section{Омар Сигурдсон и Вальгадур Стефансон}

В результате систематического отбора образцов изверженных пород из потухших геотермальных систем в земной коре Исландии была сформирована база данных, покрывающая большинство типов пород геотермальных резервуаров, эксплуатирующихся в настоящее время в Исландии. Сейчас база данных включает более 500 образцов от базальтового до риолитового состава и диапазон гидротермальных изменений от совсем свежих до пород зеленосланцевой фации. База данных используется для изучения взаимосвязи между различными параметрами коллекторов. В статье описывается взаимосвязь между пористостью и проницаемостью вместе с вытекающей из этого информацией. Установлено, что разница между эффективной и общей пористостью не превышает в среднем $2 \%$ и что эта разница не зависит от величины пористости в пределах от 0 до $50 \%$. Это показывает, что общий объем пор в изверженных породах является эффективным для протекания жидкости через породу. Проницаемость, измеренная с помощью жидкого соленого раствора, систематически ниже, чем проницаемость, полученная при измерениях с использованием воздуха или газа. Проницаемость, 
измеренная с помощью жидкого соленого раствора, в среднем в три раза ниже, чем проницаемость, измеренная с помощью газа на том же образце. Авторы объясняют это различие образованием реликтовой пленочной жидкости, которая прилипает к породе, что уменьшает и блокирует часть путей для жидкости. Модель пучка капиллярных трубок представляется наилучшим образом описывающей структуру пористости исландских пород, в то время как модель Козени-Кармана показывает очень слабую корреляцию с данными. Вычисленный диаметр в модели пучка капиллярных

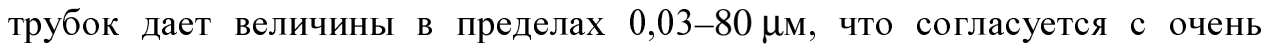
немногими лабораторными измерениями, дающими величины в пределах

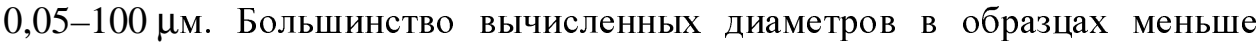
$0,7 \mu \mathrm{M}$, или меньше длины волны видимого света. 